\title{
EFFECT OF AMBIENT TEMPERATURE AND AIR FLOW RATE ON THE TEMPERATURE INSIDE THE COMPOST PILE
}

\author{
El-Sayed G. Khater*
}

\begin{abstract}
A heat balance was carried out to predict the compost pile temperature during the maturation stage. The components of the heat generation, solar radiation and heat lost by radiation, evaporation, convection and conduction were the main parts of heat balance at different ambient temperatures. Temperature was predicted at different ambient temperatures $\left(15,20,25,30\right.$ and $\left.35^{\circ} \mathrm{C}\right)$ and different airflow rates $(0.70$,

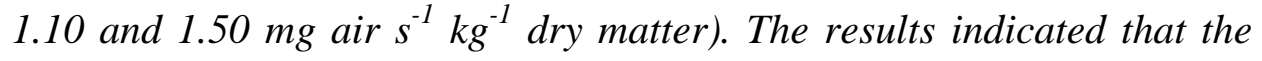
pile temperature increases with increasing ambient temperature and it decreases with increasing airflow rates, where, as the ambient temperature increased from 15 to $35^{\circ} \mathrm{C}$, the pile temperature increased from 33.40 to $43.18^{\circ} \mathrm{C}$, and when the airflow rates increased from 0.7 to $1.5 \mathrm{mg}$ air $\mathrm{s}^{-1} \mathrm{~kg}^{-1}$ dry matter, the pile temperature decreased from 38.28 to $36.05{ }^{\circ} \mathrm{C}$. The pile temperature increased slightly and reached $a$ maximum value at day 14. It indicates that the net energy gained to the pile increases with increasing ambient temperature, meanwhile, the heat lost decreases with increasing ambient temperature.
\end{abstract}

Keywords: heat balance, mathematical model, pile temperature, compost.

\section{INTRODUCTION}

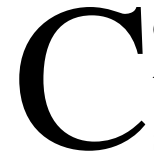
omposting is a complex process in which mass and energy transfer phenomena and microbiological degradation and nonsteady state conditions coexist. Composting is an aerobic process, which requires oxygen to stabilize the organic wastes, optimal moisture and porosity. Temperature, oxygen and moisture are considered as the control variables in the composting process, because they can be the most significant parameters in controlling the process (Haug, 1993).

* Lecturer. of Agric. Eng., Fac. of Agric., Benha Univ., Egypt. E-mail address: alsayed.khater@fagr.bu.edu.eg 
Temperature is an important factor in maintaining a proper composting system. The determination of the thermal balance in the composting process is important in understanding bioreactor dynamics and providing proper temperature control. Studying of optimal operational factors and proper control of the composting process has been reported by several researchers (Haug, 1993; Wan and Hwang, 1997; Seki, 2002).

The prediction of temperature in a composting process have been carried out in a few previous works,. Some of studies have focused on the study of surface compost temperatures of composting heaps and their relation to core temperatures (Turner $\boldsymbol{e t}$ al., 2005) in an aerated active composting pile, with the aim of inferring pathogen deactivation, since important temperature gradients have been observed in large composting masses (Sommer et al., 2004). Other works have investigated the effect of turning on the temperature and oxygen profiles in composting ((Tremier et al., 2005 and Avnimelech et al., 2004).

Mason (2006) reported that the heat generation coefficient varied between 17.8 and $24.7 \mathrm{~kJ} / \mathrm{g}$ DM removed and between 304 and 448 $\mathrm{kJ} /$ mole $\mathrm{O}_{2}$ consumed. Such variations can justify since the enthalpy of formation and the stoichiometry of bio-oxidation of every waste may depend on its biochemical composition. However, as mentioned above, the heat release is often calculated on basis of thermal balance assuming heat transfers are valid whereas determine heat transfer coefficients is rather complex and that uncertainties regards heat transfers still remain. The natural convection including evaporation and transfers between composting material and gas surrounding material were recognized as the main contributors to heat loss in detriment of radiation and Robinzon et al. (2000) estimated losses by evaporation, radiation and convection to be 70,20 and $10 \%$, respectively.

One of the main problems that face production compost is the difficulty to control the compost temperature, therefore, the main aim of this work is to develop a heat balance to predict the compost temperature during the maturation stage to help in a proper compost production at different ambient temperatures and flow rates.

\section{HEAT BALANCE OF ACOMPOST PILE}

A heat balance of the compost pile was carried out and the following assumptions were taking into consideration as follows: 
- The compost pile materials are homogeneous.

- The compost composition at the beginning is known.

- The flow rate and pressure inside the pile are uniformity distributed.

Figure (1) represents the heat balance described by the following mathematical expression:

$$
\begin{aligned}
& m C_{P} \mathrm{dT} / \mathrm{dt}=\mathrm{q}_{\text {solar }}+\mathrm{q}_{\text {gen }}-\mathrm{q}_{\text {conv }}-\mathrm{q}_{\text {cond }}-\mathrm{q}_{\text {rad }}-\mathrm{q}_{\text {evap }} \\
& \mathrm{q}_{\text {solar }}=q_{\mathrm{D}}-\mathrm{q}_{\text {sky }}-\mathrm{q}_{\text {reflected }}
\end{aligned}
$$

Where:-

$\mathrm{m}$ is the total composting mass, $\mathrm{kg}$

$\mathrm{C}_{\mathrm{p}}$ is the heat capacity of compost, $\mathrm{kJ} \mathrm{kg}^{-1} \mathrm{~K}^{-1}$

$\mathrm{T}$ is the temperature of the pile, $\mathrm{K}$

$\mathrm{t}$ is the time, day

$\mathrm{q}_{\text {solar }}$ is the generated energy by solar radiation, $\mathrm{kJ}_{\text {day }}{ }^{-1}$

$\mathrm{q}_{\mathrm{gen}}$ is the generated energy by biodegradation, $\mathrm{kJ}_{\text {day }}{ }^{-1}$

$\mathrm{q}_{\mathrm{conv}}$ is the energy loss by convection, $\mathrm{kJ}_{\text {day }}{ }^{-1}$

$\mathrm{q}_{\mathrm{cond}}$ is the energy loss by conduction, $\mathrm{kJ}_{\text {day }}{ }^{-1}$

$\mathrm{q}_{\mathrm{rad}}$ is the energy loss by radiation, $\mathrm{kJ}_{\text {day }}{ }^{-1}$

$\mathrm{q}_{\text {evap }}$ is the energy loss by water evaporation, $\mathrm{kJ}_{\text {day }}{ }^{-1}$

$\mathrm{q}_{\mathrm{D}}$ is the energy gained by direct solar radiation, $\mathrm{kJ}$ day $^{-1}$

$\mathrm{q}_{\mathrm{sky}}$ is the energy gained by long wave radiation from the sky, $\mathrm{kJ}$ day $^{-1}$

$\mathrm{q}_{\text {reflected }}$ is the solar energy reflected a way from the compost pile, $\mathrm{kJ}$ day $^{-1}$

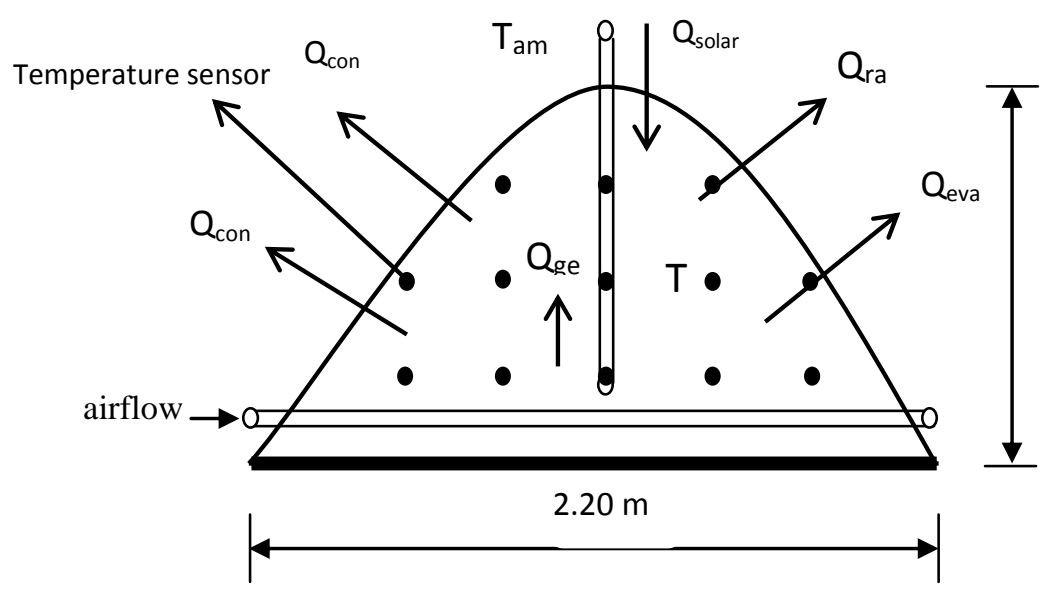

1.7

Figure (1): Heat balance of the compost pile temperature sensors distribution. 
To determine the amount of incoming extraterrestrial radiation, the following equations can be used (Holman, 1997):

$$
\begin{gathered}
q_{\text {solar }}=\Psi S_{c}\left(\frac{D}{D_{o}}\right)^{2} \cos \theta_{z} \\
\left(\frac{D}{D_{o}}\right)^{2}=1.000110+0.034221 \cos \tau+0.001280 \sin \tau+0.000719 \cos (2 \tau)+0.000077 \sin (2 \tau) \\
\tau=\frac{2 \pi(n-1)}{365}
\end{gathered}
$$

Where:

$\tau$ is the day angle, radians

$\mathrm{n}$ is the day of the year (on January $1 \mathrm{st}, \mathrm{n}=1$ )

$\mathrm{S}_{\mathrm{c}}$ is the solar constant, $\mathrm{kJ}_{\text {day }}{ }^{-1}$

$\mathrm{D}$ is the distance from the Earth to the sun, $\mathrm{km}$

$\mathrm{D}_{0}$ is the mean distance from the Earth to the sun, $1.496 \times 10^{8} \mathrm{~km}$

$\psi$ is a "clearness" factor ( 1 on clear days, most of work days are clear in Egypt)

$\theta_{\mathrm{Z}}$ is the solar zenith angle, degrees

The solar zenith $(\theta z)$ is the angle formed by the pile normal and direct incident beam radiation and this angle varies with the time of day, the time of year and the geographical position of the pile. The solar zenith is given by the following equations (Anderson, 1983 and ASHRAE, 1998):

$$
\begin{aligned}
& \cos \theta_{z}=\cos \Phi \cos \delta \cos \omega+\sin \Phi \sin \delta \\
& \delta=23.45 \sin \left[\frac{360}{365}(284+n)\right] \\
& \omega=\left(12-\omega_{\text {time }}\right) x 15^{\circ} \\
& \omega_{\text {time }}=L S T+(L n t-L n g) \div 15
\end{aligned}
$$

Where:

$\Phi$ is the pile's latitude (positive for North), degrees

$\delta$ is the solar declination (the angle formed by the line from the center of the Earth to the center of the Sun and the Earth's equator), degrees

$\omega$ is the hour angle, degrees

$\omega_{\text {time }}$ is the solar time, degrees

LST is local standard time 
Lnt is the longitude of the standard time meridian, degrees

Lng is the longitude of the pile, degrees

Longwave sky radiation can be calculated using the following equation (Bliss, 1961, Kondratyev, 1969).

$$
Q_{\text {sky }}=0.97 e \sigma\left(T_{\text {air }}\right)^{4}
$$

Where:-

$\mathrm{T}_{\text {air }}$ is absolute air temperature $2 \mathrm{~m}$ above the water surface, in Kelvin

$\mathrm{e}$ is average emittance of the atmosphere, dimensionless

The average emittance of the atmosphere terms can be calculated according to the following equations (Bliss, 1961):

$$
e=0.398 \times 10^{-5}\left(T_{\text {air }}\right)^{2.148}
$$

The reflectivity of solar radiation varies with the angle of incidence of the incoming radiation will be negligible.

Heat generated during the maturation stage can be described by the following equation (Das and Keener, 1997):

$$
\mathrm{Q}_{\mathrm{gen}}=\mathrm{h}_{\mathrm{c}} \frac{\mathrm{dm}_{\mathrm{d}}}{\mathrm{dt}}
$$

Where:-

$\mathrm{h}_{\mathrm{c}}$ is the combustion of the compost material, $\mathrm{kJ} \mathrm{kg}^{-1}$ (dry matter)

$\mathrm{m}_{\mathrm{d}}$ is the dry matter of compost, $\mathrm{kg}$

The degradation of dry matter was modeled after the equation presented by Keener et al. (1993) which is:

$$
\frac{\mathrm{dm}_{\mathrm{d}}}{\mathrm{dt}}=\mathrm{K}\left(\mathrm{m}-\mathrm{m}_{\mathrm{d}}\right)
$$

here:-

$\mathrm{K}$ is the degradation rate of compost at local temperature and moisture content, day ${ }^{-1}$

Convective heat loss is caused by the enthalpy differences between air entering and exiting the pile. It can be described by the following equation (Barrena et al., 2006):

$$
\mathrm{Q}_{\text {conv }}=\mathrm{n}_{2} \mathrm{C}_{\mathrm{P} 2}\left(\mathrm{~T}_{\text {surf }}-\mathrm{T}_{0}\right)-\mathrm{n}_{1} \mathrm{C}_{\mathrm{P} 1}\left(\mathrm{~T}_{\mathrm{amb}}-\mathrm{T}_{0}\right)
$$

Where:-

$\mathrm{n}_{1}$ is the air flow exiting the composting mass, $\mathrm{kg}$ day $^{-1}$

$\mathrm{n}_{2}$ is the air flow entering the composting mass, $\mathrm{kg}_{\text {day }}{ }^{-1}$ 
$\mathrm{C}_{\mathrm{p} 1}$ is the average heat capacity of air exiting the composting mass, $\mathrm{kJ} \mathrm{kg}^{-1} \mathrm{~K}^{-1}$

$\mathrm{C}_{\mathrm{p} 2}$ is the average heat capacity of air entering the composting mass, $\mathrm{kJ} \mathrm{kg}^{-1} \mathrm{~K}^{-1}$

$\mathrm{T}_{\text {surf }}$ is the surface temperature, $\mathrm{K}$

$\mathrm{T}_{0}$ is the standard temperature, $\mathrm{K}$

$\mathrm{T}_{\mathrm{amb}}$ is the ambient temperature, $\mathrm{K}$

Conductive and radiation heat loss terms can be calculated according to the following equations, respectively (Haug, 1993):

$$
\begin{gathered}
\mathrm{Q}_{\text {cond }}=U A\left(\mathrm{~T}_{\text {surf }}-\mathrm{T}_{\text {amb }}\right) \\
\mathrm{Q}_{\text {rad }}=\sigma A F_{a} F_{b}\left(\mathrm{~T}_{\text {surf }}^{4}-\mathrm{T}_{\text {amb }}^{4}\right)
\end{gathered}
$$

Where:-

$\mathrm{U}$ is the overall heat transfer coefficient, $\mathrm{kJ} \mathrm{m}^{-2} \mathrm{~K}^{-1}$ day $^{-1}$

$\mathrm{A}$ is the area of conduction and radiation heat transfer, $\mathrm{m}^{2}$

$\sigma$ is the Stefan-Boltzmann constant, $\mathrm{kJ} \mathrm{m}^{-2} \mathrm{~K}^{-4}$ day $^{-1}$

$\mathrm{F}_{\mathrm{a}}$ is the emissivity radiation factor

$F_{b}$ is the configurational radiation factor.

To estimate $\mathrm{T}_{\text {surf }}$, a local calorific balance was carried out, taking into account that given a heat exchange area and under pseudo-steady state conditions, the heat internally transferred from the core to the surface of the pile must be equal to the heat loss in the surface (conduction and radiation terms) as shown in the following equation (Barrena $\boldsymbol{e t}$ al., 2006):

$$
\mathrm{Q}_{\text {icond }}=Q_{\text {rad }}+\mathrm{Q}_{\text {cond }}
$$

with

$$
\mathrm{Q}_{\text {icond }}=k A\left(\mathrm{~T}-\mathrm{T}_{\text {surf }}\right) / \mathrm{dx}
$$

Where:-

$\mathrm{Q}_{\text {icond }}$ is heat internally conducted from the core to the surface of the pile, $\mathrm{kJ}_{\text {day }}{ }^{-1}$

$\mathrm{k}$ is the average thermal conductivity of compost, $\mathrm{kJ} \mathrm{m}^{-1} \mathrm{~K}^{-1}$ day $^{-1}$

$\mathrm{dx}$ is the average distance from the core to the surface, $\mathrm{m}$ Energy loss by water evaporation can be calculated by the equation 19 (Bach et al., 1987).

$$
\mathrm{Q}_{\text {evap }}=Q_{\text {gen }}-\left(\mathrm{F}_{\mathrm{wvS}} \cdot \mathrm{L}_{\text {evap }}\right)
$$

Where:-

$\mathrm{F}_{\mathrm{WVS}}$ is the flux of vapor coming out from the material, $\mathrm{kg} \mathrm{day}^{-1}$ 
$\mathrm{L}_{\text {evap }}$ is the latent heat of evaporation, $\mathrm{kJ} / \mathrm{kg}$ water evaporated The gaseous flow going out from the composting material was assumed saturated in vapour and the mass of water going out from material as vapour was calculated as (de Guardia et al., 2012):

$$
\mathrm{F}_{\mathrm{wVS}}=n_{2} \cdot \mathrm{V}_{\mathrm{s}}
$$

Where:-

$\mathrm{V}_{\mathrm{S}}$ is the vapor content in saturated gas, $\mathrm{kg}$ water/kg dry air The content in vapour in saturated gas $\left(\mathrm{V}_{\mathrm{s}}\right)$ was calculated to mathematical regression of psychometric charts between 10 and $110{ }^{\circ} \mathrm{C}$ (de Guardia et al., 2012):

$$
\mathrm{V}_{\mathrm{s}}=0.00464 \cdot \mathrm{e}^{(0.05859 \pi)}
$$

The latent heat of evaporation was obtained by applying:

$$
\mathrm{L}_{\text {evap }}=2501-2.56 \mathrm{~T}
$$

All computational procedures of the model were carried out using Excel spreadsheet. The computer program was devoted to heat balance for predicting the temperature of compost pile. Figure (2) shows the flowchart of the model.

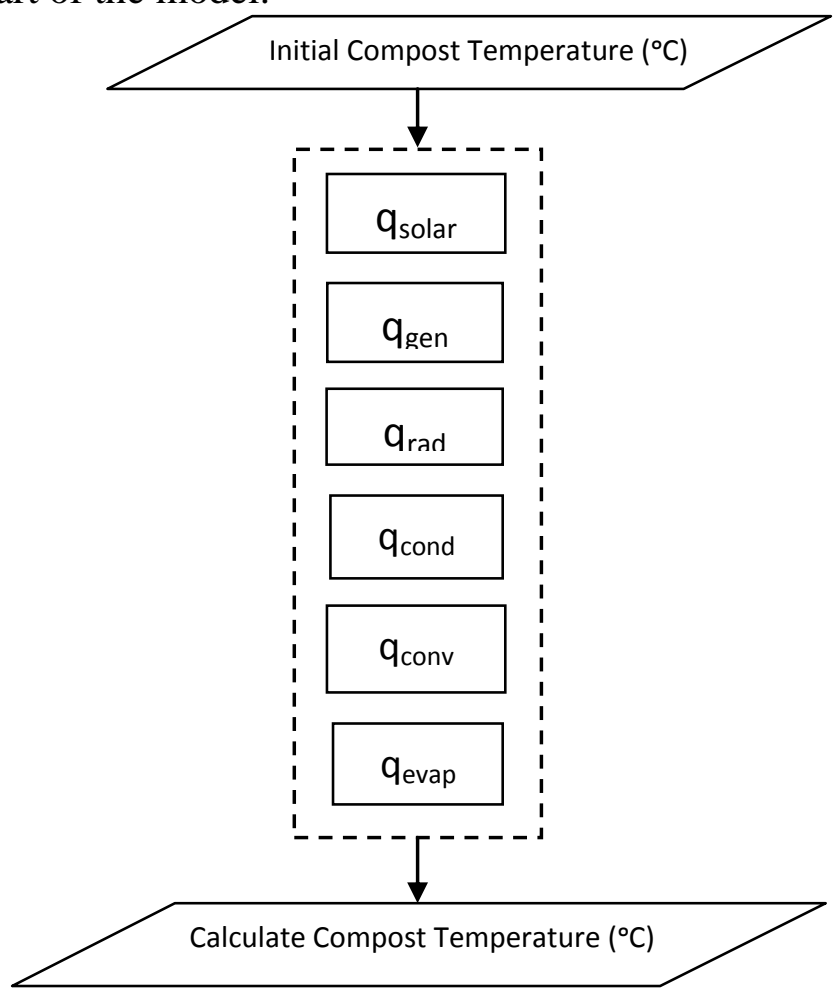

Figure (2): Flowchart of the model. 
Table (1) shows the initial (before maturation) and final (after maturation) characteristics of the maturation pile. Table (2) shows the parameters used in the model. The model results were validated by carrying out an experiment to read the temperature inside the pile at different ambient temperature.

Table (1): Initial and final characteristics of the compost pile.

\begin{tabular}{lcc}
\hline Parameter & Initial & Final \\
\hline Moisture content $(\%)$ & 50.25 & 32.40 \\
Organic matter $(\%)$ & 46.25 & 35.60 \\
$\mathrm{pH}$ & 7.60 & 7.20 \\
$\left.\mathrm{EC}(\mathrm{dS} \mathrm{m})^{-1}\right)$ & 3.65 & 3.60 \\
Bulk density $\left(\mathrm{kg} \mathrm{m}^{-3}\right)$ & 588 & 573 \\
Nitrogen content $(\%)$ & 1.11 & 1.35 \\
\hline
\end{tabular}

The parameters used in the model that were obtained from the literature are listed in table (2).

Table (2): the parameters used in the heat balance.

\begin{tabular}{|c|c|c|c|}
\hline Parameter & Units & Value & Source \\
\hline $\mathrm{h}_{\mathrm{c}}$ & $\mathrm{MJ} \mathrm{kg}^{-1}$ & 23.00 & Keener et al. (1993) \\
\hline $\mathrm{C}_{\mathrm{P}}$ oxygen & $\mathrm{kJ} \mathrm{kg}^{-1} \mathrm{~K}^{-1}$ & 29.35 & Weppen (2001) \\
\hline$C_{P}$ nitrogen & $\mathrm{kJ} \mathrm{kg}^{-1} \mathrm{~K}^{-1}$ & 29.12 & Weppen (2001) \\
\hline $\mathrm{C}_{\mathrm{P}}$ carbon dioxide & $\mathrm{kJ} \mathrm{kg}^{-1} \mathrm{~K}^{-1}$ & 37.11 & Weppen (2001) \\
\hline $\begin{array}{l}\mathrm{C}_{\mathrm{P}} \text { compost }(40 \% \\
\text { moisture })\end{array}$ & $\mathrm{kJ} \mathrm{kg}^{-1} \mathrm{~K}^{-1}$ & 2.01 & Haug (1993) \\
\hline$\Psi$ & - & 1 & Bliss (1961) \\
\hline $\mathrm{T}_{0}$ & $\mathrm{~K}$ & 298 & Haug (1993) \\
\hline Lnt & Degrees & 30 & \\
\hline Lng & Degrees & 31.2 & \\
\hline $\mathrm{F}_{\mathrm{a}}$ & - & 0.9 & Haug (1993) \\
\hline $\mathrm{F}_{\mathrm{b}}$ & - & 1.0 & Haug (1993) \\
\hline $\mathrm{U}$ & $\mathrm{kJ} \mathrm{m}^{-2} \mathrm{~K}^{-1}$ day $^{-1}$ & 100.32 & Haug (1993) \\
\hline $\mathrm{k}$ & $\mathrm{kJ} \mathrm{m}^{-1} \mathrm{~K}^{-1}$ day $^{-1}$ & 34.46 & Haug (1993) \\
\hline$\sigma$ & $\mathrm{kJ} \mathrm{m}^{-2} \mathrm{~K}^{-4}$ day $^{-1}$ & $4.89 \times 10^{-6}$ & Haug (1993) \\
\hline $\mathrm{K}$ & day $^{-1}$ & 0.29 & Keener et al. (1993) \\
\hline $\mathrm{n}_{2}$ & $\begin{array}{l}\mathrm{mg} \text { air } \mathrm{s}^{-1} \mathrm{~kg}^{-1} \\
\text { dry matter }\end{array}$ & 4320 & Barrington et al. (2003) \\
\hline A & $\mathrm{m}^{2}$ & 48.96 & \\
\hline $\mathrm{T}_{\mathrm{amb}}$ & $\mathrm{K}$ & $288-308$ & \\
\hline $\mathrm{m}$ & $\mathrm{Kg}$ & 11460 & \\
\hline
\end{tabular}




\section{EXPERIMENTAL PROCEDURES}

The experiment was carried out at the Compost Unit at Experimental Research Station at the Faculty of agriculture, Moshtohor, Benha University. Some of agricultural wastes are used for compost production, these wastes are cattle manure, herbal plants residues and sugar cane plants residues. The raw materials properties that used in the manufacturing the compost are listed in Table (3).

The mixture of raw materials was placed in three piles of $2.20 \mathrm{~m}$ wide, $1.70 \mathrm{~m}$ heigh and $12.00 \mathrm{~m}$ long. Two sets of PVC perforated pipes $5 \mathrm{~cm}$ diameter and $2.00 \mathrm{~m}$ long were placed horizontally parallel two the pile. Six pipes with same diameter were fixed vertically and distribution at $2.00 \mathrm{~m}$ distance (Figure 3).

Thirty three temperature sensors were distributed in the compost pile vertically and horizontally as shown in figure (1). Temperature was recorded at different depths $(40,80$ and $120 \mathrm{~cm}$ horizontally and $40 \mathrm{~cm}$ distance vertically) using a thermo-couple thermometer (Model DigiSense 69202-30 - Range -250 to $1800{ }^{\circ} \mathrm{C}$, USA).

Table (3): Properties of the raw materials used in compost making.

\begin{tabular}{|c|c|c|c|}
\hline \multirow[b]{2}{*}{ Properties } & \multicolumn{3}{|c|}{ Raw materials } \\
\hline & $\begin{array}{l}\text { cattle } \\
\text { manure }\end{array}$ & $\begin{array}{l}\text { herbal plants } \\
\text { residues }\end{array}$ & $\begin{array}{c}\text { sugar cane } \\
\text { plants residues }\end{array}$ \\
\hline Total Nitrogen $\%$ & 0.93 & 1.35 & 1.62 \\
\hline Total Organic Carbon $\%$ & 18.16 & 9.40 & 20.00 \\
\hline Total Organic Matter\% & 31.30 & 43.10 & 61.30 \\
\hline C/N Ratio & 19.53:1 & $6.97: 1$ & $12.35: 1$ \\
\hline Total Phosphorus \% & 0.21 & 0.36 & 1.12 \\
\hline Total Potassium \% & 0.17 & 0.42 & 1.36 \\
\hline Bulk Density $\mathrm{kg} \mathrm{m}^{-3}$ & 750.00 & 354.00 & 372.00 \\
\hline Moisture Content $\%$ & 58.30 & 16.20 & 36.20 \\
\hline
\end{tabular}

The temperature readings were used to validate the predicted temperature from the heat balance model.

\section{RESULTS AND DISCUSSION}

\section{1- Model Experimentation:}

- The predicted pile temperature at different ambient temperatures:

The average daily predicted pile temperatures at different ambient temperatures $\left(15,20,25,30\right.$ and $\left.35^{\circ} \mathrm{C}\right)$ are shown in figure (3). It indicates that the pile temperature increases with increasing ambient 
temperature. From the figure (3), it could be seen that the pile temperature increased gradually until it reached the peak after 14 day and then decreased until it reached day 40 and then it seemed to be constant. The ambient temperature increased from 15 to $35^{\circ} \mathrm{C}$ caused an increase of pile temperature by $8.78^{\circ} \mathrm{C}$ during the whole period of work. The pile temperature reached a maximum value at day 14 (72.20, 77.64, 81.61, 86.34 and $93.52^{\circ} \mathrm{C}$ at different ambient temperature 15, 20, 25, 30 and $35^{\circ} \mathrm{C}$, respectively). After the temperature peak, a progressive decrease in temperature is observed, to reach a final value of $34.40,35.61,37.17$, 40.04 and $43.18^{\circ} \mathrm{C}$ at different ambient temperature $15,20,25,30$ and $35^{\circ} \mathrm{C}$, respectively at day 50 . The temperature increase was due to the metabolic heat generated by relative stable compost piles (in terms temperature). This phenomenon is observed in pile composting, where the thermophilic temperature is only maintained for few weeks or even few days as mentioned by Petiot and de Guardia (2004).

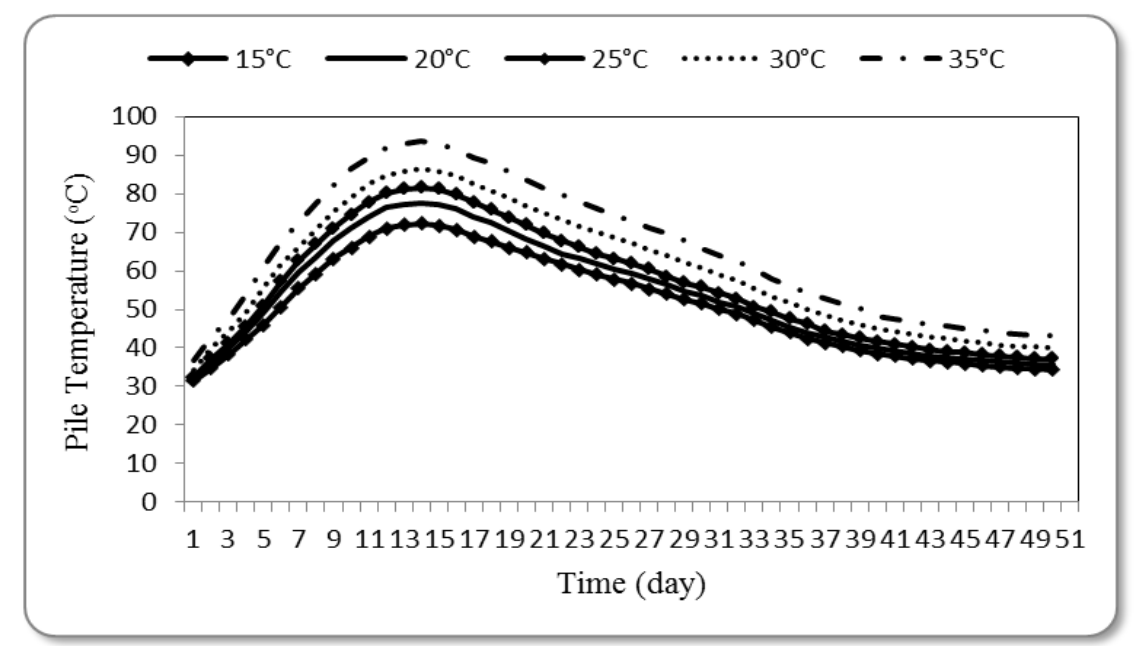

Figure (3): The average daily pile temperature at different ambient temperatures.

\section{- The predicted pile temperature at different airflow rates:}

The average daily predicted pile temperature at different airflow rates $\left(0.70,1.10\right.$ and $1.50 \mathrm{mg}$ air s $\mathrm{kg}^{-1}$ dry material) are shown in figure (4). It indicates that the pile temperature decreases with increasing airflow rates. From the figure (4), it could be seen that the pile temperature 
increased gradually until it reached the peak after 14 day and then decreased until it reached day 40 and then it seemed to be constant. It could be seen that the airflow rates increased from 0.7 to $1.5 \mathrm{mg}^{\text {air s}}{ }^{-1} \mathrm{~kg}$ ${ }^{1}$ dry material caused a decrease of pile temperature by $2.23{ }^{\circ} \mathrm{C}$ during the whole period of work. The pile temperature reached a maximum value at day $14\left(87.33,81.61\right.$ and $77.53{ }^{\circ} \mathrm{C}$ at different airflow rates $0.7,1.1$ and $1.5 \mathrm{mg}$ air s${ }^{-1} \mathrm{~kg}^{-1}$ dry material, respectively). After the temperature peak, a progressive decrease in temperature is observed, to reach a final value of 38.28, 37.17 and $36.05{ }^{\circ} \mathrm{C}$ at different airflow rates $0.7,1.1$ and $1.5 \mathrm{mg}$ air $\mathrm{s}^{-1} \mathrm{~kg}^{-1}$ dry material, respectively at day 50 . These results were agreed with those obtained by (Petric and Selimbašić, 2008). This is due to the cooling effect of the air entering the pile which had a lower temperature than that of the inside pile temperature.

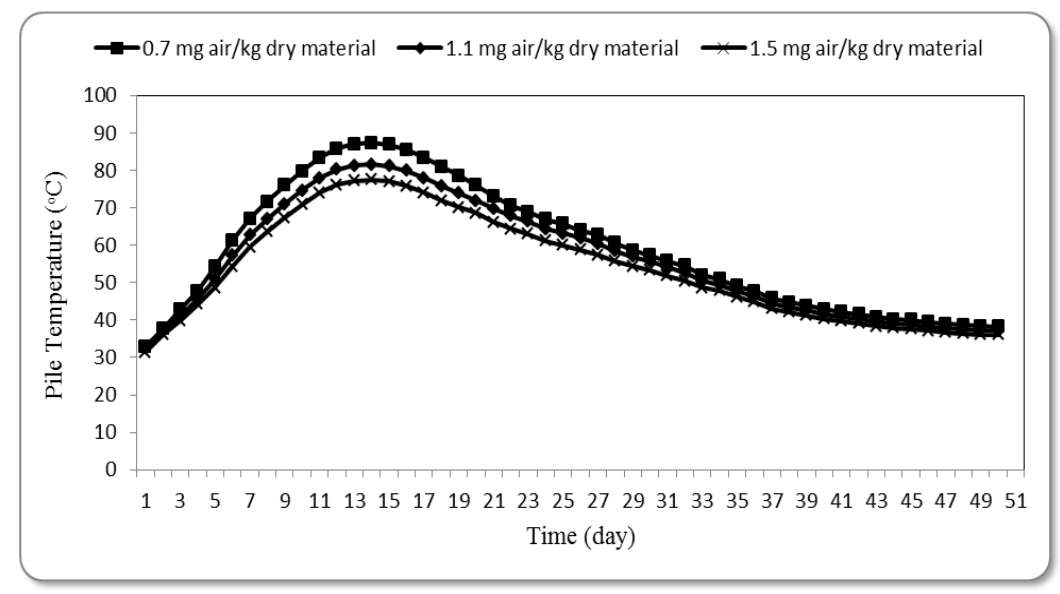

Figure (4): The average daily pile temperature at different air flow rates.

\section{- Energy balance of compost pile at different ambient temperatures:}

Table (4) shows the components of the energy balance of the compost pile which include: heat gained by heat generation, solar radiation and heat lost by radiation, evaporation, convection, and conduction at different ambient temperatures $\left(15,20,25,30\right.$ and $\left.35^{\circ} \mathrm{C}\right)$. It indicates that the net energy gained to the pile increases with increasing ambient temperature, meanwhile, the heat lost decreases with increasing ambient temperature. The results also indicate that when the ambient temperature 
increased from 15 to $35{ }^{\circ} \mathrm{C}$ the heat gained increased from 7620.67 to $9605.16 \mathrm{~kJ} \mathrm{~m}^{-2}$ day $^{-1}$ which represents 40.91 to $50.03 \%$ of total energy, but, heat loss decreased from 11005.05 to $9593.36 \mathrm{~kJ} \mathrm{~m}^{-2}$ day ${ }^{-1}$ which represents 59.09 to $49.97 \%$ of total energy.

Table (4): Energy balance of the compost pile.

\begin{tabular}{ccccc}
\hline \multirow{2}{*}{$\begin{array}{c}\text { Ambient } \\
\text { Temperature }\left({ }^{\circ} \mathrm{C}\right)\end{array}$} & \multicolumn{2}{c}{ Energy gain } & \multicolumn{2}{c}{ Energy loss } \\
\cline { 2 - 5 } $\mathrm{kJ} \mathrm{m}^{-2} \mathrm{day}^{-1}$ & \% of total energy & $\mathrm{kJ} \mathrm{m}^{-2}$ day $^{-1}$ & \% of total energy \\
\hline 15 & 7620.67 & 40.91 & 11005.05 & 59.09 \\
20 & 8206.06 & 43.34 & 10729.69 & 56.66 \\
25 & 8768.27 & 45.66 & 10434.88 & 54.34 \\
30 & 9114.84 & 47.55 & 10055.35 & 52.45 \\
35 & 9605.16 & 50.03 & 9593.36 & 49.97 \\
\hline
\end{tabular}

\section{2- Model Validation:}

The model was validated using the experimental data and other data from the relevant studies of (Ahn et al., 2007 and Barrena et al., 2006). Figure (5) shows the predicted, the measured temperatures, model data of (Ahn et al., 2007) and model data of (Barrena et al., 2006) of compost pile during the maturation stage.

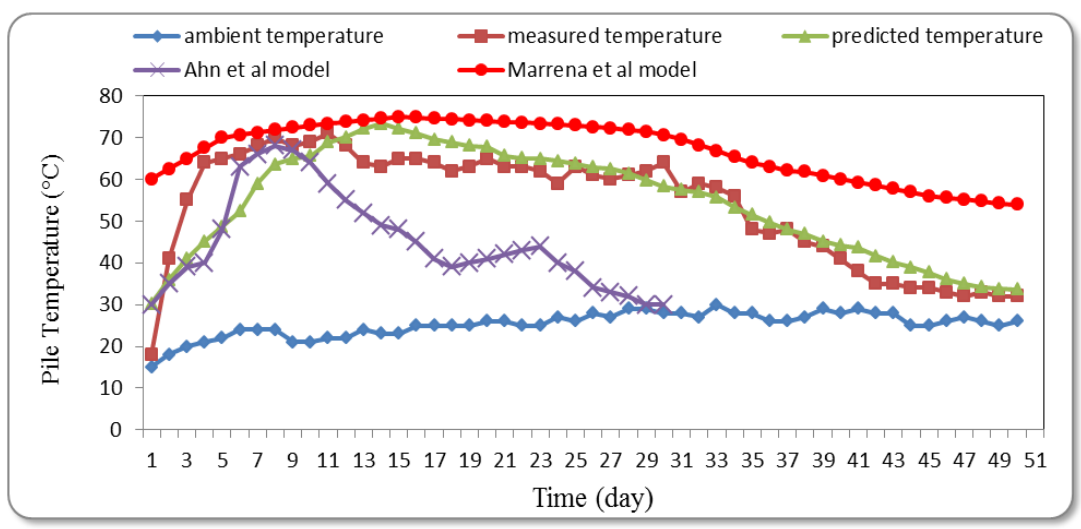

Figure (5): The predicted and the measured temperatures of compost pile during the whole period of compost.

It could be seen that, the average daily pile temperature by the model was in a reasonable agreement with those measured, where, it ranged 31.72 to $76.34{ }^{\circ} \mathrm{C}$ theoretically while it was from 18.00 to $71.00{ }^{\circ} \mathrm{C}$ experimentally during the whole period. The pile temperature reaches a maximum value 
at day $14\left(73.40{ }^{\circ} \mathrm{C}\right)$ theoretically, while it was $71.00{ }^{\circ} \mathrm{C}$ at day 11 experimentally. The mode results were in agreement with the data obtained by (Ahn $\boldsymbol{e t}$ al., 2007), while the data obtained by (Barrena $\boldsymbol{e t}$ al., 2006), were higher than the experimental data, which is owing to overestimating the heat generation in addition to, he considered the energy loss by evaporation does not change during the whole process.

The variations between the predicted and the measured are shown in figure (6). The relationship between the predicted and measured temperatures is expressed by the following equation:

$$
\mathrm{T}_{\mathrm{P}}=0.8872 \mathrm{~T}_{\mathrm{M}}+9.9576 \quad \mathrm{R}^{2}=0.93
$$

Where:

$\mathrm{T}_{\mathrm{P}}$ is the predicted pile temperature, ${ }^{\circ} \mathrm{C}$

$\mathrm{T}_{\mathrm{M}}$ is the measured pile temperature, ${ }^{\circ} \mathrm{C}$

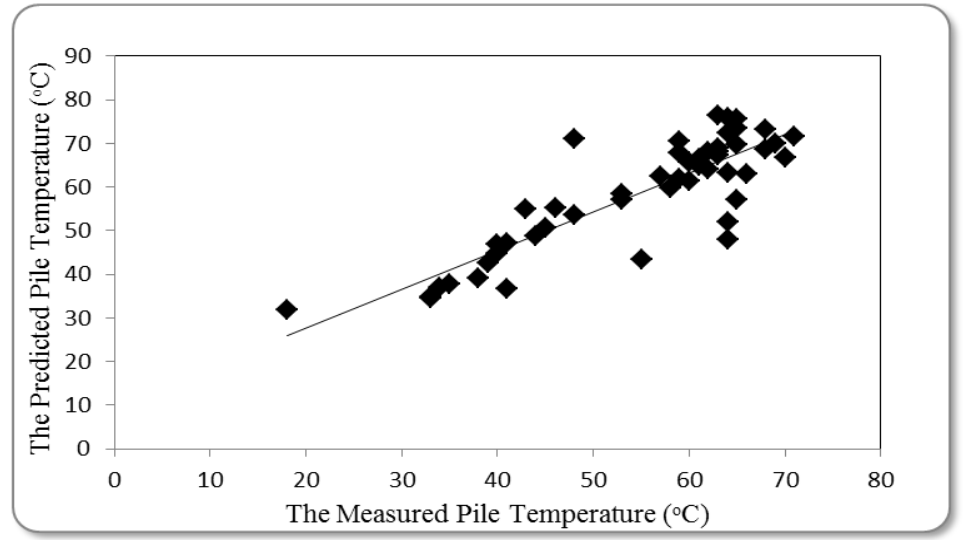

Figure (6): The comparison between the predicted and the measured temperatures of compost pile during the whole period of compost.

\section{CONCLUSIONS}

A heat balance model for the compost system was developed successively according to optimizes the main factors affecting the performance of compost system through studying of pile temperature at different ambient temperatures and air flow rates. Also, carrying out an experiment to validate the model results through measuring: pile temperature. The most important results obtained can be summarized as follows:

- The model showed that the predicted pile temperature increases with increasing the ambient temperature, where, the ambient air 
temperature increased from 15 to $35^{\circ} \mathrm{C}$ during the whole period of compost, the predicted pile temperature increased from 34.40 to $43.18^{\circ} \mathrm{C}$.

- The model showed that the predicted daily pile temperature decreases with increasing the airflow rate, where, the airflow rates increased from 0.7 to $1.5 \mathrm{mg}$ air $\mathrm{kg}^{-1}$ dry matter during the whole period of compost, the predicted pile temperature decreased from 38.28 to $36.05^{\circ} \mathrm{C}$.

- The predicted pile temperature was in a reasonable agreement with the measured pile temperature with a coefficient of determination of 0.93 . The average daily pile temperature ranged from 31.72 to 76.34 ${ }^{\circ} \mathrm{C}$, while it was from 18.00 to $71.00{ }^{\circ} \mathrm{C}$ experimentally during the whole period.

\section{REFERENCES}

Ahn, H. K., Richard, T. L., Choi, H. L., 2007. Mass and thermal balance during composting of a poultry manure - Wood shavings mixture at different aeration rates. Process Biochemistry 42 (2), 215-223.

Anderson, E.E., 1983. Fundamentals of Solar Energy Conversion. Addison-Wesley Publishing Company. Reading, Mass. 636 pp.

ASHRAE, 1998. Handbook Fundamentals. American Society of Heating, Refrigeration and Air Conditioning Engineers, Atlanta, GA.

Avnimelech, Y., Eilat, R., Porat, Y., Kottas, P.A., 2004. Factors affecting the rate of windrow composting in field studies. Compos. Sci. Util. 12, 114-118.

Bach, P. D., Nakasaki, K., Shoda, M., Kubota, H., 1987. Thermal balance in composting operations. Journal of Fermentation Technology, 65 (2), 199-209.

Barrena, R., Canovas, C., Sánchez, A., 2006. Prediction of temperature and thermal inertia effect in the maturation stage and stockpiling of a large composting mass. Waste Management 26, 953 - 959.

Barrington, S., Choiniere, D., Trigui, M., Knight, W., 2003. Compost convective airflow under passive aeration. Bioresource Technol. 86: 259 - 266.

Bliss, R. W., Jr., 1961. Atmospheric Radiation near the Surface of the Ground. Solar Energy 5:103-120. 
Das, K., Keener, H. M., 1997. Numerical model for the dynamic simulation of a large scale composting system. Transactions of the ASAE, 40 (4), 1179-1189.

de Guardia, A., Petiot, C., Benoist, J. C., Druilhe, C., 2012. Characterization and modelling of the heat transfers in a pilotscale reactor during composting under forced aeration. Waste Management 32, 1091 - 1105.

Haug, R.T., 1993. The Practical Handbook of Compost Engineering. Lewis Publishers, Boca Raton, FL.

Holman, J.P., 1997. Heat Transfer, 8th edition. McGraw-Hill. 696 pp.

Keener, H. M., Marugg, C., Hansen, R. C., Hoitink, H. A. J., 1993. Optimizing the efficiency of the composting process. In Science and Engineering of Composting: Design Environmental, Microbiological, and Utilization Aspects, pp. $59-94$. Worthington, Ohio: Renaissance Publications.

Kondratyev, Ya K., 1969. Radiation in the Atmosphere. Academic Press. Inc. 912 pp. 155.

Mason, I. G., 2006. Mathematical modelling of the composting process: a review. Waste Management 26 (1), 3-21.

Moraga, N. O., Corvalan, F., Escudey, M., Arias, A., Zambra, C. E., 2009. Unsteady $2 D$ coupled heat and mass transfer in porous media with biological and chemical heat generations. International Journal of Heat and Mass Transfer, 52 (25-26), 5841-5848.

Petiot, C., de Guardia, A., 2004. Composting in a laboratory reactor: a review. Compos. Sci. Util. 12, 69-79.

Petric, I. Selimbašić, V., 2008. Development and validation of mathematical model for aerobic composting process. Chemical Enginering Journal, 139: 304 - 317.

Robinzon, R., Kimmel, E., Avnimelech, Y., 2000. Energy and mass balances of windrow composting system. Transactions of ASAE, 43 (5), 1523-1529.

Seki, H., 2002. A new deterministic model for forced aeration composting processes with batch operation. Trans ASAE, 45:1239 -1250 .

Sommer, S.G., McGinn, S.M., Hao, X., Larney, F.J., 2004. Techniques for measuring gas emissions from a composting stockpile of cattle manure. Atmos. Environ. 38, 4643-4652. 
Tremier, A., de Guardia, A., Massiani, C., Paul, E., Martel, J.L., 2005. A respirometric method for characterising the organic composition and biodegradation kinetics and the temperature influence on the biodegradation kinetics, for a mixture of sludge and bulking agent to be cocomposted. Bioresource Technol. 96: $169-180$.

Turner, C., Williams, A., White, R., Tillett, R., 2005. Inferring pathogen inactivation from the surface temperatures of compost heaps. Bioresource Technol. 96, 521-529.

Wan, N. K., Hwang, E. Y., 1997. Opeational parameters for composting night soil in Korea. Compost Sci Utilization, 5:46 - 51.

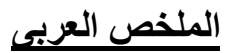 \\ تأثير درجة الحرارة المحيطة ومعدل سريان الهواء على درجة الحرارة داخل

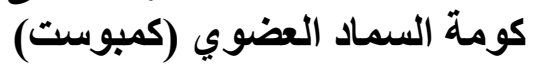 \\ * السيد جمعه خاطر}

تهدف هذا الدراسة إلى تطوير نموذج رياضى لانتاج السماد العضوى وأهم العو امل التى تؤثر

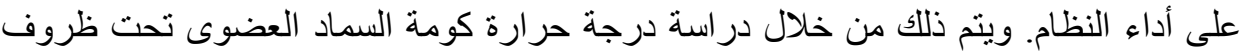

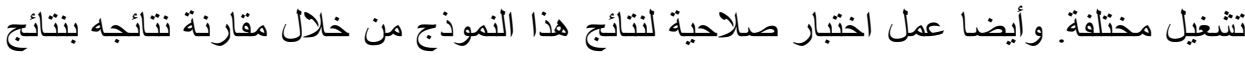

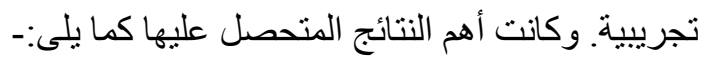

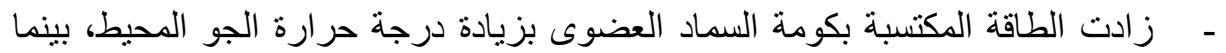

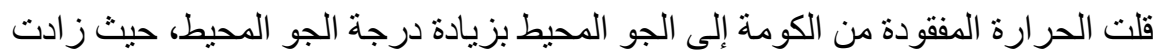

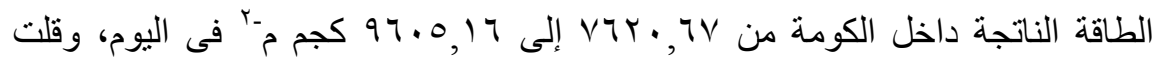

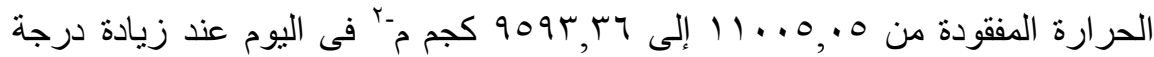

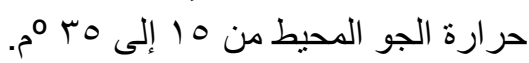
زادت درجة حرارة السماد العضوى بزيادة درجة حرة حرارة الجو المحيط، حيث زادت

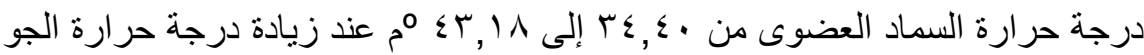

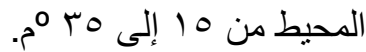

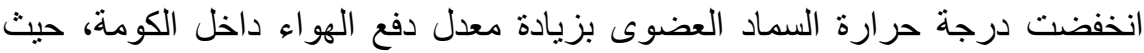

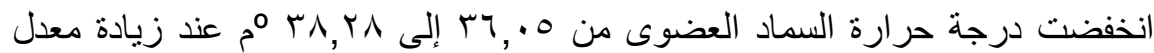

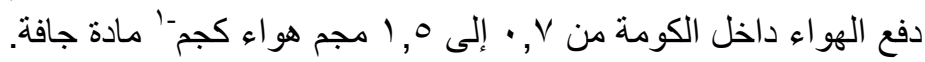

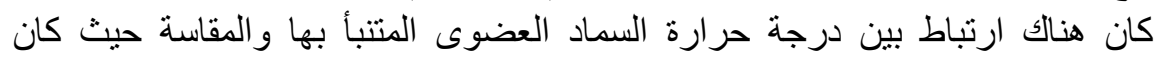

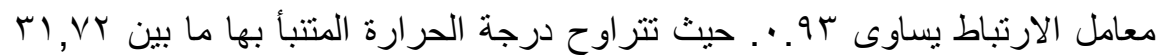

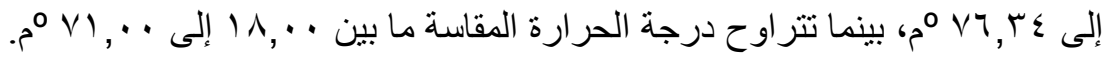

